\title{
Cost Estimates of Producing Sapodilla in South Florida, $2017^{1}$
}

\author{
Edward A. Evans, Fredy H. Ballen, Aditya Singh and Jonathan H. Crane ${ }^{2}$
}

\section{Introduction}

Sapodilla (Manilkara zapota) is a tropical member of the Sapotaceae family. The exact origin of sapodilla is not clear; it is considered native to Mexico, Guatemala and possibly also El Salvador, Honduras, Colombia and Venezuela. Over time, sapodilla was introduced to other parts of the world. Today, the fruit is cultivated under a wide range of tropical and subtropical climatic conditions. The Philippines, India, and Mexico are the main world producers, respectively (IBPGR 1986).

Sapodilla may have been introduced into Florida from the Bahamas in the 1800s (Ledesma 2013). Commercial sapodilla production in the United States occurs in south Florida. There are numerous cultivars, with the bearing season in Florida extending from February to September (Campbell et al. 1997; Campbell and Ledesma 2002; Crane et al. 2016). A mature tree yield ranges from 50 to 80 pounds of fruit, depending on cultivar, planting density, and cultural practices. Major commercial cultivars include 'Alano,' 'Hasyá,, 'Morena, 'Prolific', and 'Tikal'. South Florida commercial sapodilla production area is estimated at 150 acres (Crane, personal communication). Assuming a planting density of 100 trees per acre, a conservative yield of 6,500 pounds per acre (Coronel 1991), and an average F.O.B. Homestead price (i.e., the price at the packinghouse) of $\$ 1.80$ per pound, the crop is worth about $\$ 1.75$ million at the farm gate level.

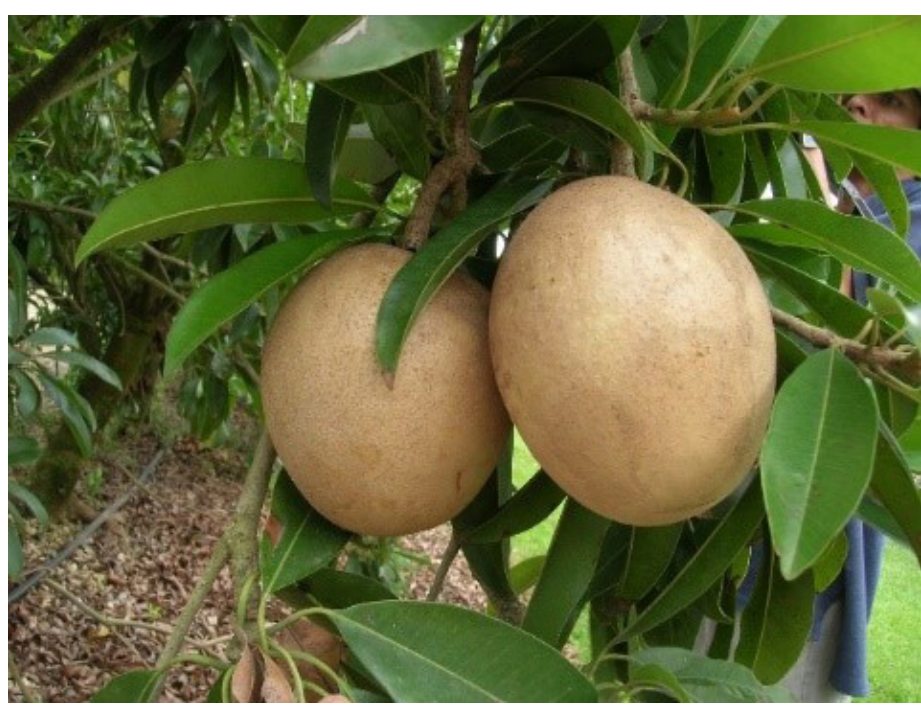

Credits: Jonathan Crane, UF/IFAS TREC

This publication provides an estimate of the costs and returns associated with an established sapodilla orchard in south Florida. The information presented here is based on a wide range of production practices collected through field interviews with growers and industry specialists and, as such, is intended only as a guide to estimate the financial aspects of operating an established sapodilla grove.

Please note that sapodilla has been assessed by the UF/IFAS Invasive Plants Working Group as potentially invasive in south and central Florida.

1. This is EDIS document FE1015, a publication of the Food and Resource Economics Department, UF/IFAS Extension. Published December 2017. Visit the EDIS website at http://edis.ifas.fu.edu.

2. Edward A. Evans, Interim Center Director and Professor, Food and Resource Economics Department; Fredy H. Ballen, Data Management Analyst II; Aditya Singh, Research Scholar, and Jonathan H. Crane, Tropical Fruit Crop Specialist, UF/IFAS Tropical Research and Education Center, Homestead, FL.

The Institute of Food and Agricultural Sciences (IFAS) is an Equal Opportunity Institution authorized to provide research, educational information and other services

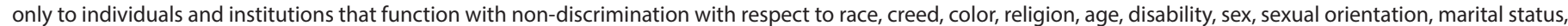

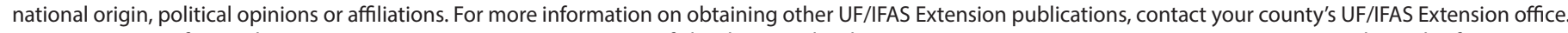
U.S. Department of Agriculture, UF/IFAS Extension Service, University of Florida, IFAS, Florida A \& M University Cooperative Extension Program, and Boards of County Commissioners Cooperating. Nick T. Place, dean for UF/IFAS Extension. 
To prevent the unwanted spread of this plant, the following recommendations for commercial sapodilla plantings have been developed:

1. Do not plant sapodilla trees in home landscapes or in commercial groves abutting natural areas.

2. Reduce on-farm habitat (e.g., unmanaged areas of the grove) suitable for wildlife attracted to and capable of consuming sapodilla fruit and moving seed to natural areas.

3. Surround commercial plantings of sapodilla trees with fencing to reduce or prevent wildlife intrusion.

4. Bury, crush, or compost sapodilla fruit not consumed to prevent wildlife from eating it and transporting the seeds.

5. Move harvested fruit either in covered vehicles or under tarps.

For more information, visit the UF/IFAS Assessment of Non-Native Plants in Florida's Natural Areas (https://assessment.ifas.ufl.edu/) and the UF/IFAS Center for Aquatic and Invasive Plants (https://plants.ifas.ufl.edu/).

\section{Main Assumptions}

Using the following assumptions, Table 1 shows the average annual costs and returns associated with operating a one-acre sapodilla grove. The budget and production cost items are for a one-acre orchard on a per-year basis. Given that tropical fruit growers in south Florida own the land, a rental cost of $\$ 500 /$ acre/year is used for the opportunity cost of the land. Due to the diversity of cultural practices and managerial styles found, average costs and returns are reported for the present analysis.

\section{Orchard Layout}

Under south Florida conditions, sapodilla plantings are spaced 25 to 30 feet between-rows and 15 to 20 feet inrows, resulting in a planting density ranging from 72 to 145 trees per acre. The present analysis considers a density of 100 trees/acre.

\section{Revenue}

Yield - On the basis of the information provided by growers, yield ranges from 5,000 to 8,000 pounds per acre per year; hence the average marketable yield is about 6,500 pounds per acre per year.

Sapodilla Prices - The average F.O.B. (Homestead) price for sapodilla is estimated at $\$ 1.80$ per pound. This value is calculated from the prices growers received from packinghouses in 2016.

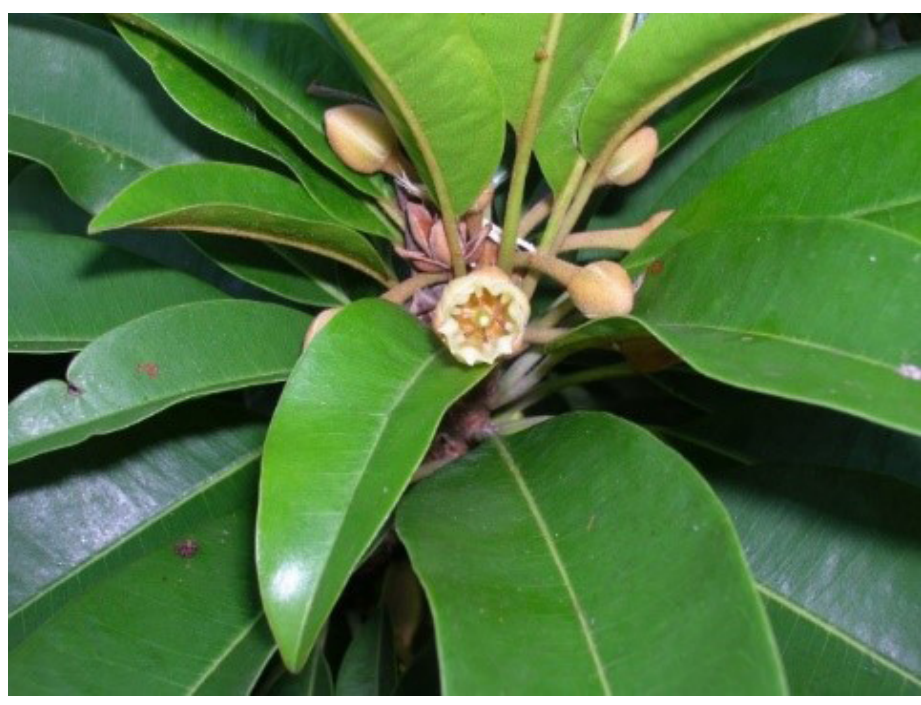

Figure 1. Sapodilla flowers.

Credits: Jonathan Crane, UF/IFAS TREC.

\section{Production Costs}

The major components of the production costs (or variable costs) include hired labor (74\%), fertilizers (9\%), insecticides (4\%), and fungicides (3\%), respectively. Production costs total $\$ 3,217$ (about $\$ 0.49$ per pound).

Irrigation - Mature sapodilla trees are somewhat drought tolerant but produce best if irrigated periodically from flowering through harvest (Crane et al. 2016). Average irrigation expenses comprised of fuel or electricity costs are estimated at $\$ 70 /$ acre/year.

Fertilization - Fertilizer treatments for mature trees include applications of 6-6-6 fertilizer (nitrogen, phosphate, and potash), soil-drench applications of chelated iron, and minor element foliar sprays. Average fertilization costs (materials only) are estimated at \$288/acre/year.

Pest Management - Sapodilla has relatively few insect pests of economic importance (Crane and Mossler 2013). Pests of importance include several moth species, such as Banisia argutula, which causes extensive damage to blooms and fruit (Martinez et al. 2017). There are no major sapodilla diseases of importance in south Florida; diseases that cause minor damage include leaf rust (Uredo sapotae), septoria leaf spot (Septoria sp.), and dry rot (Fusarium solani). Weed management practices include herbicide applications, hand weeding, and mulching (Crane et al. 2016). Average agrochemical costs (materials only) are estimated as follows: insecticides (\$127/acre/year), fungicides (\$100/acre/year), and herbicides (\$92/acre/year), respectively. 
Labor - Besides wages, labor includes agricultural input application costs (e.g., fertilizers and agrochemicals) and cultural operations costs (e.g., irrigation, pruning, and mowing). Labor costs are estimated at $\$ 2,387 /$ acre/year.

Interest on capital - This is the cost of borrowing money or the opportunity cost for using equity. A rate of $5 \%$ was considered in the present analysis.

\section{Fixed Costs}

These are the costs incurred even if no fruit is produced. They include cash overhead costs (e.g., insurance and taxes), non-cash overhead costs (e.g., land rent), and other overhead costs (e.g., machinery use, electricity, telephone, computer, and other office expenses) which are estimated at $\$ 1,125$. Although growers own the land, the going rate of $\$ 500$ per acre for land rental is used to reflect the opportunity cost of the land. Including the land rental charge, total fixed costs are estimated at $\$ 1,625 /$ acre/year ( $\$ 0.25 /$ pound).

\section{Harvesting and Marketing Costs}

Sapodilla harvesting requires detailed inspection to pick the fruit at the right maturity level (Figure 2). Fruit picked at optimum maturity usually ripen in 4 to 10 days. Trees may have harvestable fruit year-round, with the main season varying with the cultivar (Crane et al. 2016). The cost for harvesting and marketing sapodilla is estimated at $\$ 451 /$ acre/year (\$0.07/pound).

Figure 3 illustrates the magnitude of the costs by category, and their respective share of the total. Production costs (e.g., pruning, fertilization, and pest control) account for $59 \%$ of the total cost, followed by fixed costs (30\%), harvest and marketing cost (8\%), and interest on capital (3\%), respectively.

\section{Returns and Profitability Analysis}

The information provided in Table 1 shows that the total cost to produce and market one acre of sapodilla is estimated at $\$ 5,293 /$ acre/year ( $\$ 0.81 /$ pound). Based on an average marketable yield of 6,500 pounds/acre and the aver-age F.O.B Homestead price (delivered to the packinghouse) of $\$ 1.80$ /pound, the total receipt or gross revenue is

$\$ 11,700 /$ acre/year.

Subtracting total variable cost (total production cost plus harvesting and marketing cost) from total revenue, we obtain a gross margin of $\$ 8,032 /$ acre/year ( $\$ 1.24$ /pound) which exceeds by far the gross return of other tropical fruits grown in the area, such as avocado ( $\$ 0.15 /$ pound). The gross margin provides a useful indicator of short-term

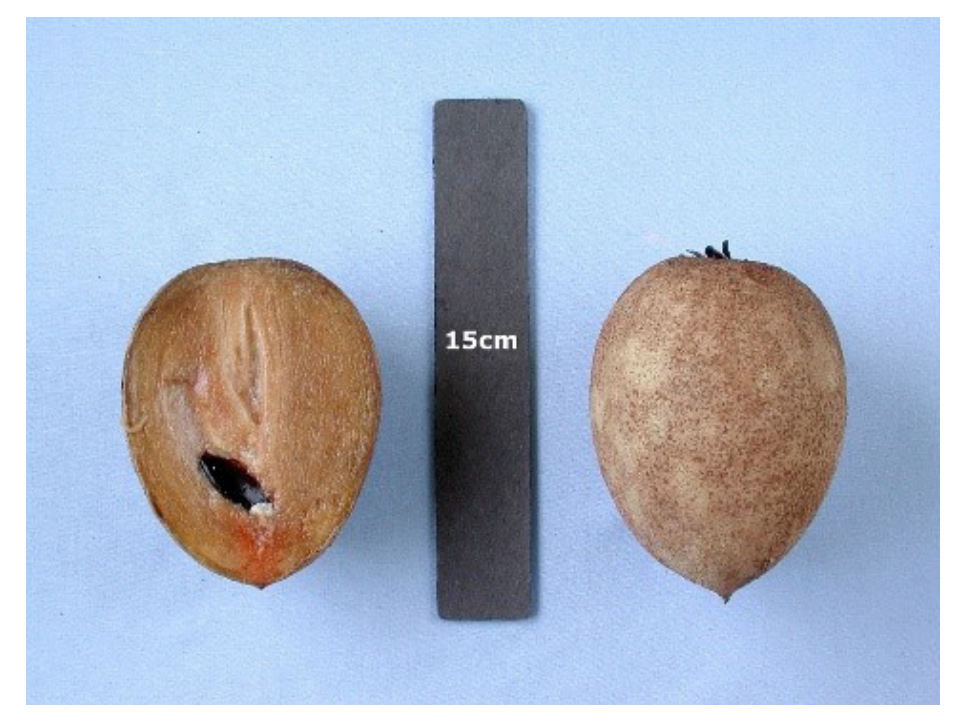

Figure 2. 'Tikal' sapodilla.

Credits: I. Maguire, UF/IFAS TREC.

profitability. A positive gross margin implies that all variable costs have been covered by the income generated and that additional funds remain to cover some or all of the fixed costs.

A negative gross profit implies that a business is not viable in the short term, and changes are needed to continue operating. Many growers are only concerned with the gross margin. However, while the gross margin provides an indication of return to the grower, it does not include fixed costs and, hence, is not a true reflection of the long-term viability of the business.

Net return is obtained by subtracting the fixed cost from the gross margin and is used to measure the long-term profitability of the farming operation. Table 1 shows a net return of $\$ 6,407 /$ acre/year ( $\$ 0.99 /$ pound), still a very attractive economic return compared to other tropical fruit crops in the area.

\section{Sensitivity Analysis}

Table 2 presents an analysis based on gross margin (gross profit) per acre, and the short-term economic viability of a sapodilla grove operation. Under the best-case scenario, where both price and yield are assumed to increase by $10 \%$, gross margin per acre would increase from $\$ 8,032$ / acre to $\$ 10,489 /$ acre. Under the worst-case scenario, where both price and yield decrease by $10 \%$, gross margin per acre would decrease from $\$ 8,032 /$ acre to $\$ 5,809 /$ acre. The information presented in Table 2 can be interpreted in a similar manner to that presented in the subsequent Table 3 , noting that this is with respect to gross profit, which ignores the fixed cost estimates. 


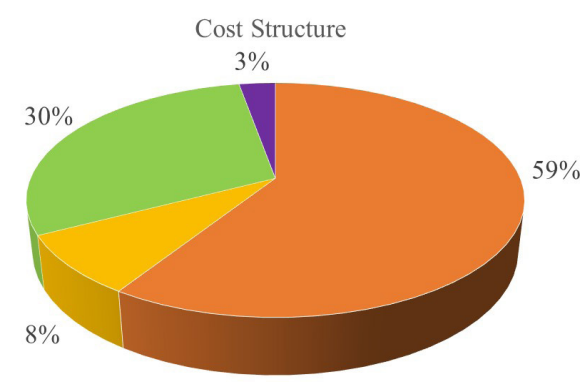

- Total production cost

- Total fixed cost

Total harvest and marketing cost

- Interest on capital

Figure 3. Total cost of sapodilla production in south Florida Credits: Fredy H. Ballen, Aditya Singh, Edward A. Evans, and Jonathan H. Crane, UF/IFAS TREC.

Table 3 presents a similar analysis based on net returns to a grower on a per-acre basis. Under the best-case scenario where both price and yield are assumed to increase by $10 \%$, net return per acre would increase from $\$ 6,407 /$ acre to $\$ 8,864 /$ acre. Under the worst-case scenario, where both price and yield decrease by $10 \%$, net return per acre would decrease from $\$ 6,407 /$ acre to $\$ 4,184 /$ acre. Other combinations of changes of prices and yields and their impact on net return per acre are also shown in Table 3. However, it should be noted that at the industry level, a noticeable increase in production usually results in a decrease in the price received by the growers.

\section{Conclusions}

The average net return obtained from an established sapodilla grove in south Florida is about $\$ 6,407 /$ acre, or $\$ 0.99$ / pound. The size of the net return makes this minor tropical fruit crop an interesting option compared to other tropical fruit crops grown in the area. However, it is important to remember that the information presented in this document refers to an established grove. We do not consider the profitability of establishing a new sapodilla grove, which includes land acquisition and development, planting costs, amortized capital costs, etc. Because sapodilla is a niche market, any sizable increases in production may result in market saturation and reduced prices.

\section{References}

Campbell, R.J., and N. Ledesma. 2002. "The sapodilla and green sapote's potential in tropical America." Proceedings of the InterAmerican Society of Tropical Horticulture 46: 55-56.

Campbell, R.J., G. Zill, and H. Mahdeem. 1997. "New sapodilla cultivars with commercial potential." Proceedings of the InterAmerican Society of Tropical Horticulture 41: 215-218.
Coronel, R.E. 1991. Manilkara zapota (1.) P. van Royen. In Plant Resources of South-East Asia, No. 2: Edible Fruits and Nuts, edited by E.W.M. Verheij and R.E. Coronel, pp. 220-223. Wageningen, Netherlands: Pudo-DLO.

Crane, J.H., C.F. Balerdi, and I. Maguire. 2016. Sapodilla Growing in the Florida Home Landscape. HS1. Gainesville: University of Florida Institute of Food and Agricultural Sciences. https://edis.ifas.ufl.edu/pdffiles/MG/MG05700. pdf

Crane, J.H., and A.M. Mossler. 2013. Florida Crop / Pest Management Profile: Mamey Sapote and Sapodilla. ECIR1414. Gainesville: University of Florida Institute of Food and Agricultural Sciences. http://edis.ifas.ufl.edu/ pdffiles/PI/PI05400.pdf.

IBPGR 1986. Sapodilla. Genetic Resources of Tropical and Sub-tropical Fruits and Nuts. Rome: IBPRG (International Board for Plant Genetics Research). http://pdf.usaid.gov/ pdf_docs/PNAAW619.pdf.

Ledesma, N. 2013. Sapodilla (Chiku) as a Delicate Dessert. Coral Gables, FL: Fairchild Tropical Botanic Garden. http:// www.fairchildgarden.org/news-pressroom-media-center/ articles/artmid/515/articleid/973.

Martinez, J.I., J.E. Hayden, J.B. Heppner, J.E. Pena, L. Xiao, and D. Carrillo. 2017. "Banisia argutula (Lepidoptera: Thyrididae) is the dominant Sapodilla borer in southern Florida." Florida Entomologist 100(1): 57-62. http://www. bioone.org/doi/abs/10.1653/024.100.0110.

UF/IFAS. 2017. Assessment of Non-Native Plants in Florida's Natural Areas. Gainesville: University of Florida Institute of Food and Agricultural Sciences. http://assessment.ifas.ufl. edu/. 
Table 1. Recurring costs per year of producing sapodilla on a south Florida one-acre orchard

\begin{tabular}{|c|c|c|c|}
\hline \multirow[t]{2}{*}{ Item } & Quantity & Value per acre & Value per pound \\
\hline & (pounds) & (\$/acre/year) & (\$/pound) \\
\hline \multicolumn{4}{|l|}{ Revenue } \\
\hline Marketable yield (lbs./acre) & 6,500 & & \\
\hline F.O.B. Homestead price & & & 1.80 \\
\hline Total revenue & & 11,700 & \\
\hline \multicolumn{4}{|l|}{ Production costs } \\
\hline Irrigation & & 70 & \\
\hline Fertilizer & & 288 & \\
\hline Herbicide & & 92 & \\
\hline Insecticide & & 127 & \\
\hline Fungicide & & 100 & \\
\hline Labor cost & & 2,387 & \\
\hline Interest on capital (5\%) & & 153 & \\
\hline Total production cost & & 3,217 & 0.49 \\
\hline \multicolumn{4}{|l|}{ Fixed costs } \\
\hline Cash overhead: & & & \\
\hline Insurance & & 100 & \\
\hline Taxes & & 100 & \\
\hline \multicolumn{4}{|l|}{ Non-cash overhead: } \\
\hline Land rent & & 500 & \\
\hline Other overhead & & 925 & \\
\hline Total fixed cost & & 1,625 & 0.25 \\
\hline Total pre-harvest cost & & 4,842 & 0.74 \\
\hline \multicolumn{4}{|l|}{ Harvest and marketing costs } \\
\hline Picking and sales costs & & 451 & 0.07 \\
\hline Total harvest and marketing costs & & 451 & 0.07 \\
\hline Total cost & & 5,293 & 0.81 \\
\hline Gross margin & & 8,032 & 1.24 \\
\hline Estimated net return & & 6,407 & 0.99 \\
\hline
\end{tabular}

Table 2. Sensitivity analysis, gross margin per acre

\begin{tabular}{|l|l|c|c|c|c|c|}
\hline \multicolumn{1}{|l|}{ Yield } \\
(pounds/acre) & \multicolumn{5}{c|}{ Wholesale price } \\
\hline & & \multicolumn{5}{|c|}{ (dollars/pound) } \\
\hline & & 1.62 & 1.71 & 1.80 & 1.89 & 1.98 \\
\hline 5,850 & $(-10 \%)$ & $(-5 \%)$ & $($ base) & $(+5 \%)$ & $(+10 \%)$ \\
\hline 6,175 & $(-5 \%)$ & 5,809 & 6,336 & 6,862 & 7,389 & 7,915 \\
\hline 6,500 & (base) & 6,336 & 6,891 & 7,447 & 8,003 & 8,559 \\
\hline 6,825 & $(+5 \%)$ & 6,862 & 7,447 & 8,032 & 8,617 & 9,202 \\
\hline 7,150 & $(+10 \%)$ & 7,389 & 8,003 & 8,617 & 9,231 & 9,846 \\
\hline
\end{tabular}


Table 3. Sensitivity analysis, net returns per acre

\begin{tabular}{|c|c|c|c|c|c|c|}
\hline \multicolumn{2}{|l|}{ Yield } & \multicolumn{5}{|c|}{ Wholesale price } \\
\hline \multicolumn{2}{|c|}{ (pounds/acre) } & \multicolumn{5}{|c|}{ (dollars/pound) } \\
\hline & & 2.46 & 2.59 & 2.73 & 2.87 & 3.00 \\
\hline & & $(-10 \%)$ & $(-5 \%)$ & (base) & $(+5 \%)$ & $(+10 \%)$ \\
\hline 5,850 & $(-10 \%)$ & 4,184 & 4,711 & 5,237 & 5,764 & 6,290 \\
\hline 6,175 & $(-5 \%)$ & 4,711 & 5,266 & 5,822 & 6,378 & 6,934 \\
\hline 6,500 & (base) & 5,237 & 5,822 & 6,407 & 6,992 & 7,577 \\
\hline 6,825 & $(+5 \%)$ & 5,764 & 6,378 & 6,992 & 7,606 & 8,221 \\
\hline 7,150 & $(+10 \%)$ & 6,290 & 6,934 & 7,577 & 8,221 & 8,864 \\
\hline
\end{tabular}

